Original Research Article

\title{
Mutagenic Studies of male meiosis in chromium treated accessions of Eleusine coracana
}

\author{
Kumar, Anil ${ }^{1}$, Dhingra, Gulshan Kumar $^{1}$ and Gupta, Shalabh ${ }^{2}$ \\ ${ }^{1}$ Department of Botany, Govt. P.G. (Autonomous) College Rishikesh, Dehradun, Uttarakhand, India \\ ${ }^{2}$ Department of Botany, S.B.S. Govt. P.G. College, Rudrapur, Uttarakhand, India \\ Corresponding Author: singhaniya.akr@gmail.com
}

\begin{abstract}
A R T I C L E I N F O
Received: 01 February 2018 | Accepted: 22 April 2018 | Published Online: 15 August 2018

DOI: $10.31786 / 09756272.18 .9 .1 .106$

EOI: 10.11208 /essence.18.9.1.106

Article is an Open Access Publication.

This work is licensed under Attribution-Non Commercial 4.0 International

(https://creativecommons.org/licenses/by/4.0/)

CThe Authors (2018). Publishing Rights @ MANU-ICMANU \& ESSENCE-IJERC.
\end{abstract}

\begin{abstract}
A B S T R A C T
The mutagenic effect of heavy doses of $\mathrm{Cr}$ on male gametophyte development were investigated in two accessions of genus Eleusine coracana (E1 and E2) by using parameters like chromosome configuration at metaphase I/diakinesis, chiasmata/chromosome frequency, number of spores/tetrad, pollen size and pollen sterility. Both the accessions had $2 n=18$. The frequency of chiasmata/chromosome was found to be $>0.7$ and $<0.8$ in the treated plants. The meiotic course was found to be abnormal in all the treatments and their frequency of anomalies increased with the increase in $\mathrm{Cr}$ concentration. Abnormalities noticed were restitution nucleus, clumping, chromatin bridges at telophase I/II, micronuclei at telophase I and II, etc. The spore arrangement was found to be tetrahedral. Triads and polyads were also found along with tetrads. The pollen sterility in E1 treatment were found to be 32 to $34 \%$ and in E2 from 33 to 34\%. The pollen/anther in E1 different treatments varied from 251 to 309 and in E2 from 285 to 311 . The pollen diameter in E1 was found to be 27 to $35 \mu \mathrm{m}$ and in E2 from 31 to $38 \mu \mathrm{m}$.
\end{abstract}

\section{K E Y W O R D S}

Chromium effects | Male meiosis | Eleusine coracana

\section{I T A T I O N}

Kumar, Anil, Dhingra, Gulshan Kumar and Gupta, Shalabh (2018): Mutagenic Studies of male meiosis in chromium treated accessions of Eleusine coracana. ESSENCE Int. J. Env. Rehab. Conserv. IX (1): $38-45$. 


\section{Introduction}

Cereals constitute a major source of food for the human population of the world. Important cereals in day to day use are rice, wheat and millets. Of all the millets Eleusine contains more percentage of different nutrients as compared to rice and wheat. It is a rich source of calcium, magnesium and potassium. Eleusine is nutritionally very rich cereal and is a staple food for poor and invalids (Panda, 1999). Finger millet contains more fiber, minerals and vitamins, which are normally deficient in the Indian diet, and has eight times more calcium than other cereals. The high calcium, high soluble fiber, low fat and low glycemic index of malted grains is effective in controlling the blood glucose levels of diabetics. Finger millet is especially valuable as it contains amino acid methionine, which is lacking in the diets of millions of the poor people. Finger millet can be ground and cooked into cakes, puddings or porridge. The grain is made into a fermented drink (or beer) in many parts of Africa. The straw from finger millet is used as animal fodder. It is also used for as a flavored drink in festivals. It has been shown that the nutrient level in the medium has profound effect on callus induction and subsequent plant regeneration (Ramage and Williams 2002). In Eleusine coracana the chromosome base number has been reported to be $x=9$ and $2 n=18,20,36$, and 40. Diploid (2x) and tetraploid (4x) levels are found. Chromosomes are 'small'. Haploid nuclear DNA content varies from 0.7-0.8 pg. Mean diploid i.e. $2 \mathrm{c}$ DNA value is $1.4 \mathrm{pg}$ ( 1 species). The nucleoli are persistent (Watson and Dallwitz, 1992). Some in vitro work on E. coracana has been done by Kamble et al, (2004). In E. coracana mostly in vitro work has been done Mohanty et al., (1985), Eapen and George (1989), Sivadas et al., (1990); Kumar et al., (2001).

Chromium is important for metallurgical industry. Chromium is the second most common heavymetal contaminant in groundwater, soil and sediments. Chromium phyto-toxicity has been considered to be inhibitory for plant growth, its presence in excess amount within the plant can cause stunted shoot growth and poor root development.
Much research has been conducted to determine the toxic effects of chromium on different plant species. The plants growing near industries emitting liquid pollutants or air pollutants or solid waste do not survive. This is because the heavy metals cause changes in their genetic contents thus leading to abnormal phenotype and irregular meiosis. These plants do not produce normal seeds. In the present work two accessions of Eleusine coracana were subjected to heavy $\mathrm{Cr}$ doses and the mutagenic changes induced in their male gametophyte development were studied.

\section{Materials and Methods}

For the present cytogenetic analyses two accessions of Eleusine coracana were procured from local sources Chaubattakhal $(1600 \mathrm{~m}$ asl $)$ and Uttarkashi (1200m asl). To see the effect of $\mathrm{Cr}$ on the development of male gametophyte various concentrations of $\mathrm{Cr}$ were prepared $\left(10^{-1} \mathrm{M}\right.$ to $10^{-}$ ${ }^{10} \mathrm{M}$ from stock solution of potassium dichromate). The seeds of the accessions were kept in different concentrations for 24 and 48 hours. The seeds after treatment were sown in polybags having vermiculite. The plants obtained were then transferred to agriculture field. For the male meiosis floral buds of desirable age were collected from the mature plants and fixed in Carnoy's fluid II (6:3:1:: absolute ethanol: chloroform: glacial acetic acid) for 24 hours and then transferred in $70 \%$ ethanol and stored in refrigerator. Anthers were smeared and squashed in $1.5 \%$ acetocarmine for studying meiosis. All the observations and photomicrographs were taken from unsquashed and squashed temporary preparations.buds of desirable age were collected from the mature plants and fixed in Carnoy's fluid II (6:3:1:: absolute ethanol: chloroform: glacial acetic acid) for 24 hours and then transferred in $70 \%$ ethanol and stored in refrigerator. Anthers were smeared and squashed in 1.5\% aceto-carmine for studying meiosis. All the observations and photomicrographs were taken from un-squashed and squashed temporary preparations.

Various cytological parameters analyzed during the work were:

1. Chromosome configuration at metaphase $\mathrm{I} /$ 
diakinesis, including the chiasmata frequency,

2. Types and frequency of various meiotic anomalies,

3. Number of spores per tetrad,

4. Pollen size,

5. Pollen sterility, and

6. Number of pollen per anther.

Pollen sterility was measured by staining the pollen grains with $1 \%$ aceto-carmine for overnight. The pollen grains were considered viable only if they were uniformly stained.

\section{Results and Discussion}

Detailed study of male meiosis was worked out in both the accessions of Eleusine coracana. The parameters analyzed, for working out the details of male meiosis are listed with materials and methods. The Eleusine coracana had $2 \mathrm{n}=18$ established at metaphase I and anaphase I (plate 1 e). Data related to frequency distribution of chromosome configuration at metaphase I, chiasmata per PMC and chiasmata per chromosome are listed in table 1. Mostly bivalents were observed. In treated plants a number of abnormalities were observed in the course of male meiosis and their percent distributions are given in Table 2. The treated sets exhibited the following meiotic anomalies:

1. Restitution nucleus formation at first meiotic division (plate $1 \mathrm{a}$ ).

2. Retarded movements of bivalents for metaphase I alignments (plate $1 \mathrm{~d}$ ) and chromosomes for metaphase II.

3. Random grouping at metaphase I (plate $1 \mathrm{c}$ )

4. Clumping of chromosomes at metaphase I (plate $1 \mathrm{~b}$ ) and metaphase II.

5. Precocious disjunction of chromosomes at metaphase I and chromatids at metaphase II.

6. Late disjunction of bivalents at metaphase I and chromatids at metaphase II.

7. Laggards at anaphase I (plate 1f) and anaphase II.

8. Chromatin bridges at telophase I (plate $1 \mathrm{~g}$ ) and telophase II.

9. Micronuclei at telophase I and telophase II.

Microspores were arranged in isobilateral type tetrads (plate $1 \mathrm{~h}$ ). The polyads were also ob- served. All the treated sets were analysed for the frequency of pollen sterility and number of pollen grains. The data related to mean number of pollen per anther, pollen size and pollen sterility is depicted in table 3. Graphical representation of number of pollens per anther is shown in figure 1. The size of fertile pollen grains is shown in figure 2 at different concentrations in accessions E1 and E2. The percent pollen sterility in both the accessions E1 and E2 is graphically shown in figure 3 . The number of pollens per anther in control of E1 accession was found to vary from 251 to 309 . With the increase in $\mathrm{Cr}$ concentration, number of pollens per anther decreased up to 72 in 10-3 M. Similarly in E2, the number of pollens per anther in control varied from 285 to 311 . The number of pollens found to be decreased with increase in $\mathrm{Cr}$ concentrations. In 10-3 M, the number of pollens per anther was found to be 78. In E1 control, the pollen size varied from 27 to $35 \mu \mathrm{m}$. The pollen size also decreased with the increase in $\mathrm{Cr}$ concentrations. In 10-3 M, pollen size was lowest (21 $\mu \mathrm{m})$. In E2 control, the pollen size varied from 31 to $38 \mu \mathrm{m}$ and on increasing $\mathrm{Cr}$ concentrations level the pollen size reduced up to $23 \mu \mathrm{m}$. The maximum pollen sterility in both E1 and E2 was found in higher concentration of $\mathrm{Cr}$ (10-3 M). It varied from 32.44 to $33.92 \%$ in E1 and 33.15 to $34.00 \%$ in E2 with increasing order of $\mathrm{Cr}$.

The chromatin agglutination also resulted in clumping of chromosomes at metaphase, anaphase and chromatin bridges. Late resolution of chromosomes/chromatids resulted in late disjunction. Random grouping of chromosomes/ chromatids resulted in late disjunction. Random grouping of chromosomes in more than one group at metaphase I may be due to 'longitudinal splitting' of spindle. The retarded movement of bivalents and chromosomes for metaphase I and II alignments respectively may be due to malfunctioning of microtubules responsible for the displacement of chromosomes. Lagging of chromosomes during anaphase I and II may be due to:

1. Delayed resolution of chromosomes/ chromatids of the bivalents/ chromosomes, or

2. Malfunctioning of the spindle apparatus. 
ESSENCE_-IJERC | Anil et al. (2018) | IX (1): 38-45

The bridges were chromatin bridges produced because of the stretching of chromosome segments between poles. The stretching of the chromosomes was due to chromatin agglutination in the chromosome segments. Lagging of the chromosomes resulted into micronuclei formation. Triads and polyads were also observed. Triads were formed due to arrest of meiosis in one of the two sister dyad cells after first meiotic division. The polyads were formed due to cytoplasmic partitioning of additional nuclei at the end of meiosis. The reason for these additional nuclei is the formation of micronuclei from laggards. The pollen size varied to a large extent and the percent sterility also increased with the increase in $\mathrm{Cr}$ concentrations.

\begin{tabular}{|c|c|c|c|c|c|c|c|c|c|c|c|}
\hline & 预 & $\begin{array}{l}\infty \\
\infty \\
\vdots \\
0\end{array}$ & \begin{tabular}{l}
$\stackrel{\bullet}{\infty}$ \\
\hdashline
\end{tabular} & $\vec{\infty}$ & $\begin{array}{l}\infty \\
\infty \\
0\end{array}$ & $\begin{array}{l}\vec{\infty} \\
0 \\
0\end{array}$ & $\begin{array}{c}8 \\
\infty \\
0\end{array}$ & $\begin{array}{c}\tilde{D} \\
0 \\
0\end{array}$ & $\stackrel{2}{\circ}$ & $\begin{array}{l}\mathbb{8} \\
: \\
0\end{array}$ & $\begin{array}{l}\infty \\
\infty \\
0 \\
0\end{array}$ \\
\hline & 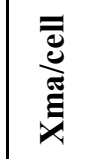 & $\begin{array}{l}0 \\
\infty \\
i \\
\qquad\end{array}$ & 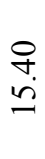 & $\begin{array}{l}\dot{B} \\
\dot{ \pm}\end{array}$ & $\begin{array}{l}\stackrel{P}{+} \\
\dot{I}\end{array}$ & $\begin{array}{l}\stackrel{8}{0} \\
\dot{ \pm}\end{array}$ & $\begin{array}{l}\stackrel{P}{+} \\
\dot{I}\end{array}$ & $\begin{array}{l}0 \\
\infty \\
\dot{ \pm}\end{array}$ & $\stackrel{\text { ঙิ }}{\underset{ \pm}{ \pm}}$ & $\begin{array}{l}\stackrel{0}{\infty} \\
\Xi \\
=\end{array}$ & $\begin{array}{l}0 \\
\infty \\
\end{array}$ \\
\hline & 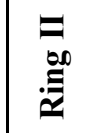 & $\begin{array}{l}\stackrel{8}{\infty} \\
\stackrel{0}{0}\end{array}$ & fọ & $\begin{array}{c}8 \\
i \\
\text {. }\end{array}$ & $\begin{array}{l}\text { Pे } \\
\dot{v}\end{array}$ & $\begin{array}{l}\stackrel{8}{0} \\
\dot{r}\end{array}$ & $\begin{array}{l}\stackrel{9}{+} \\
\dot{n}\end{array}$ & $\begin{array}{l}0 \\
\infty \\
i n\end{array}$ & $\begin{array}{l}\text { तु } \\
\text { in }\end{array}$ & $\begin{array}{l}0 \\
\infty \\
i\end{array}$ & $\begin{array}{l}0 \\
\infty \\
0 \\
0\end{array}$ \\
\hline$\tilde{\mathbf{x}}$ & $\begin{array}{l}\Xi \\
\bar{\Xi} \\
\check{a}\end{array}$ & तે & $\begin{array}{l}\stackrel{8}{B} \\
i\end{array}$ & $\begin{array}{l}q \\
\dot{m}\end{array}$ & $\begin{array}{l}8 \\
\dot{r} \\
\dot{1}\end{array}$ & $\begin{array}{l}\stackrel{q}{+} \\
\dot{r}\end{array}$ & $\begin{array}{c}8 \\
\dot{B} \\
\dot{r}\end{array}$ & 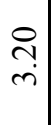 & $\begin{array}{l}\infty \\
\ddot{m}\end{array}$ & तి & $\begin{array}{l}\text { तิ } \\
\text { i }\end{array}$ \\
\hline & 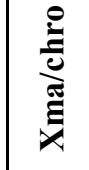 & {$\left[\begin{array}{l}\infty \\
\infty \\
\vdots \\
0\end{array}\right.$} & 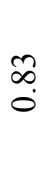 & $\mid \begin{array}{c}1 \\
\infty \\
0 \\
0\end{array}$ & $\stackrel{2}{0}$ & $\mid \begin{array}{c}0 \\
0 \\
0\end{array}$ & $\stackrel{2}{0}$ & $\begin{array}{c}\bar{\infty} \\
\dot{0}\end{array}$ & $\stackrel{?}{\circ}$ & $\begin{array}{l}\infty \\
\stackrel{0}{0} \\
0\end{array}$ & $\begin{array}{l}\infty \\
\infty \\
0 \\
0\end{array}$ \\
\hline & 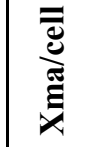 & $\begin{array}{l}\infty \\
\infty \\
\stackrel{n}{ }\end{array}$ & $\begin{array}{l}8 \\
i \\
\text { in }\end{array}$ & $\mid \begin{array}{l}\infty \\
\dot{ \pm} \\
\dot{ \pm}\end{array}$ & $\begin{array}{l}\stackrel{ }{+} \\
\pm \\
\pm\end{array}$ & $\mid \begin{array}{l}\stackrel{+}{+} \\
\dot{+}\end{array}$ & 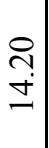 & $\begin{array}{l}\dot{8} \\
\dot{ \pm} \\
-\end{array}$ & $\begin{array}{l}\text { ָे } \\
\pm \\
\end{array}$ & $\begin{array}{c}\stackrel{\sim}{ } \\
\underset{\Xi}{\Xi}\end{array}$ & $\begin{array}{l}\infty \\
\dot{n} \\
\ddot{n}\end{array}$ \\
\hline & 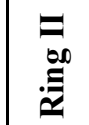 & $\begin{array}{l}\stackrel{8}{\infty} \\
\stackrel{0}{0}\end{array}$ & \&. & $\begin{array}{l}\infty \\
\dot{1}\end{array}$ & $\begin{array}{l}\text { तે } \\
\text { in }\end{array}$ & $\mid \begin{array}{c}9 \\
\dot{v} \\
\end{array}$ & $\begin{array}{l}\stackrel{\overbrace{}}{1} \\
\text { in }\end{array}$ & $\begin{array}{l}8 \\
\dot{0} \\
\text {. }\end{array}$ & $\begin{array}{l}\text { तิ } \\
\text { in }\end{array}$ & $\begin{array}{l}\stackrel{\text { }}{1} \\
\text { r. }\end{array}$ & $\begin{array}{l}8 \\
0 \\
0\end{array}$ \\
\hline$\vec{a}$ & $\begin{array}{l}\Xi \\
\stackrel{0}{0} \\
\simeq\end{array}$ & 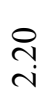 & $\underset{\dot{m}}{\stackrel{8}{m}}$ & $\begin{array}{l}\stackrel{i}{1} \\
\text { ñ. }\end{array}$ & $\begin{array}{l}\otimes \\
\dot{r} \\
\dot{m}\end{array}$ & $\begin{array}{c}8 \\
\dot{0} \\
\dot{m}\end{array}$ & $\begin{array}{l}\stackrel{D}{\infty} \\
\dot{r}\end{array}$ & $\begin{array}{l}\stackrel{9}{+} \\
\text { r. }\end{array}$ & $\begin{array}{l}\infty \\
\dot{m} \\
\dot{m}\end{array}$ & $\begin{array}{l}\infty \\
\infty \\
i\end{array}$ & 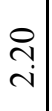 \\
\hline $\mid \begin{array}{c}\dot{e} \\
\ddot{\Xi} \\
\dot{U} \\
\dot{U}\end{array}$ & & 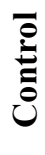 & 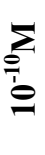 & $\sum_{i}$ & $\sum_{\substack{i \\
0 \\
\varrho}}$ & 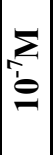 & 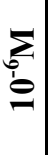 & $\begin{array}{l}\sum_{n} \\
0 \\
0\end{array}$ & $\sum_{\substack{+\varrho}}$ & $\begin{array}{l}\sum_{p} \\
\stackrel{\theta}{\theta}\end{array}$ & $\begin{array}{l}\sum_{i=1} \\
\varrho \\
=\end{array}$ \\
\hline
\end{tabular}

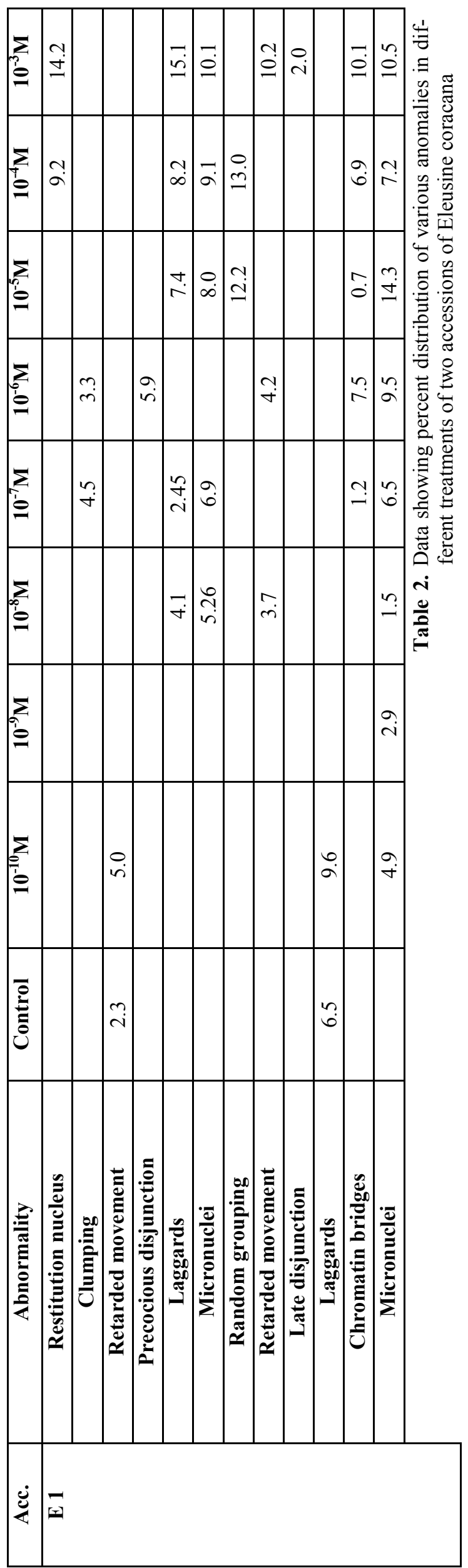


ESSENCE_IJERC | Anil et al. (2018) | IX (1): 38—45

\begin{tabular}{|c|c|c|c|c|c|c|c|c|c|c|}
\hline$\sum_{i=0}^{\infty}$ & & & & & $\stackrel{n}{n}$ & & $\stackrel{\sim}{\sim}$ & & $\stackrel{m}{\sim}$ & 9 \\
\hline$\sum_{t}^{+}$ & $\stackrel{0}{\simeq}$ & & & $\stackrel{q}{ \pm}$ & & $\begin{array}{l}\infty \\
\infty\end{array}$ & & & $\hat{\alpha}$ & o \\
\hline$\sum_{\substack{n \\
0 \\
0}}$ & $\stackrel{n}{0}$ & $\stackrel{+}{\stackrel{\sim}{\sim}}$ & ơ & & 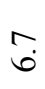 & $\stackrel{1}{0}$ & & নे. & $\stackrel{\infty}{\sim}$ & \\
\hline
\end{tabular}

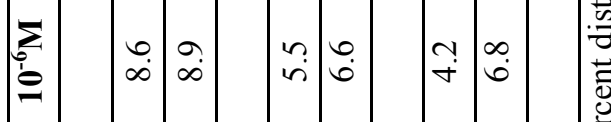

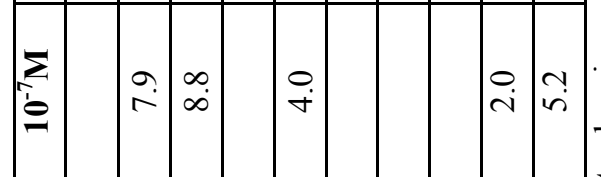

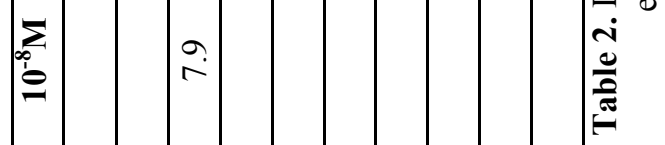
$\sum_{\substack{0 \\ i=}} \mathfrak{r}$

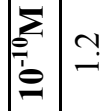

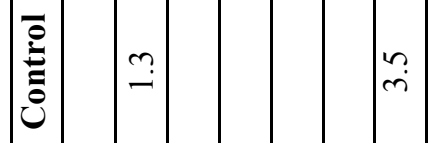

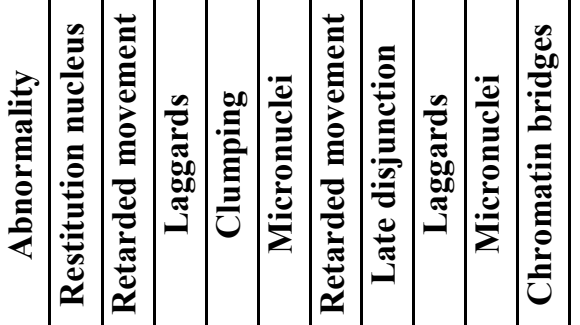

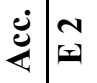

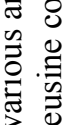

岁䒠

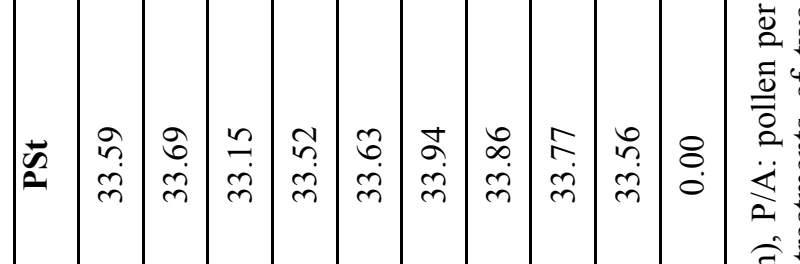

(્己

$2 \leqslant$ 누

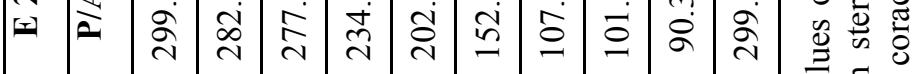

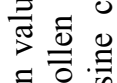

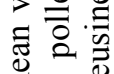

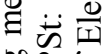

की

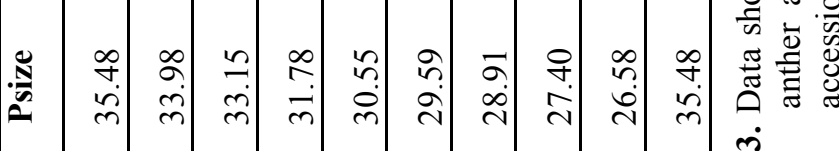

官

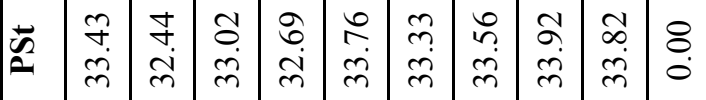

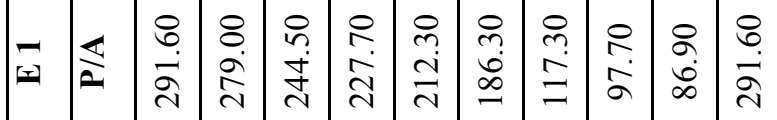

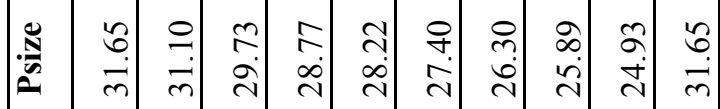

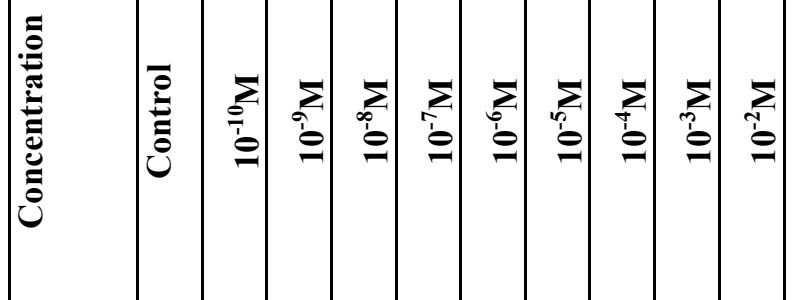


ESSENCE-IJERC | Anil et al. (2018) | IX (1): 38-45
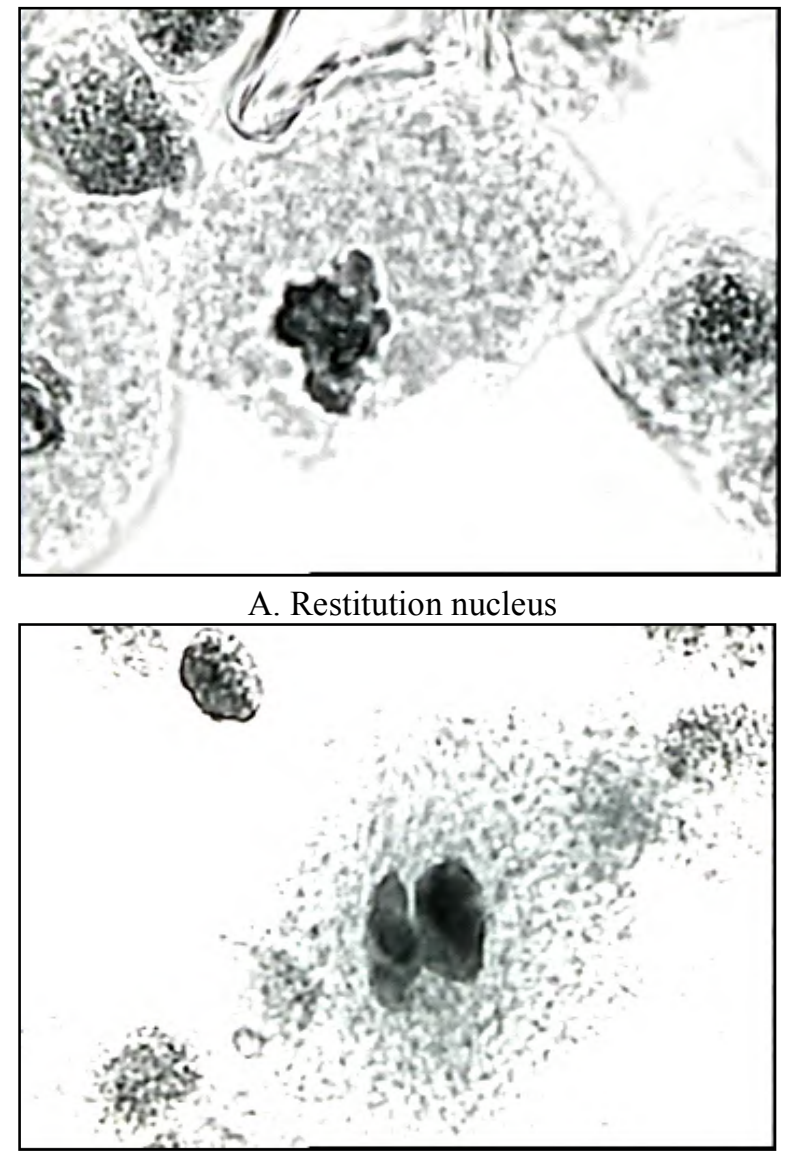

B. Clumping at metaphase I

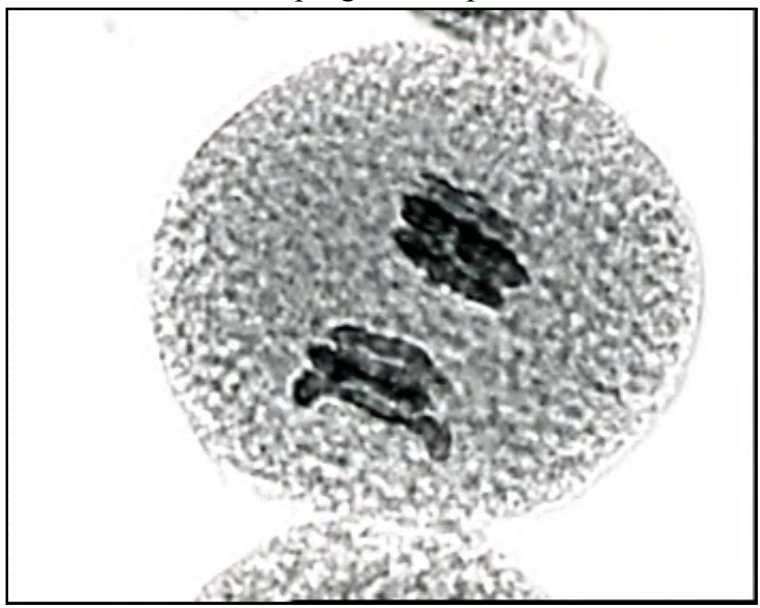

C. Random grouping at Metphase I

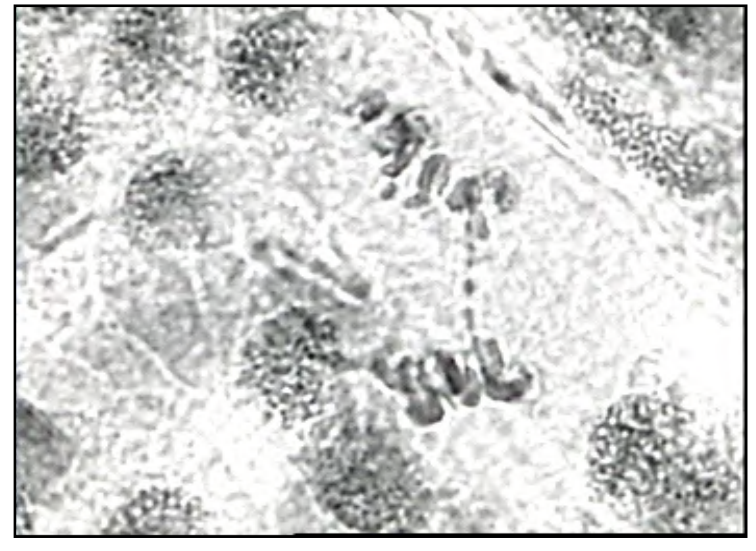

G. Chromatin bridge at Anaphase I

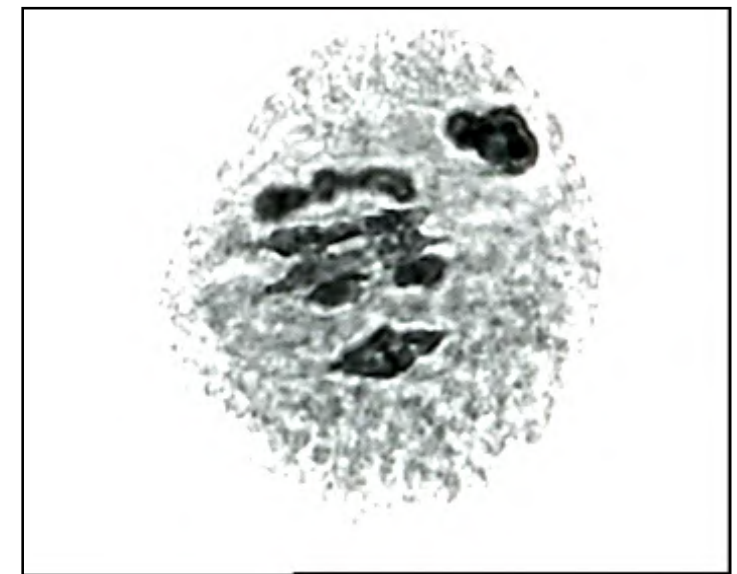

D. Retarded movement of bivalent

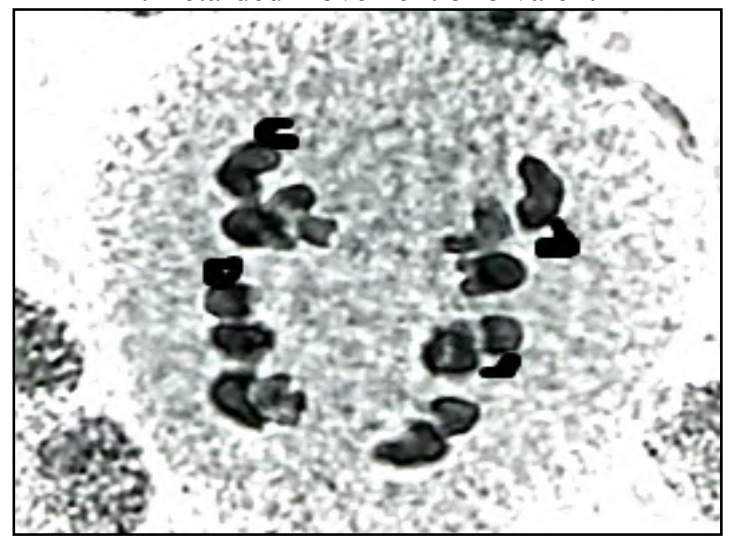

E. Normal Anaphase I

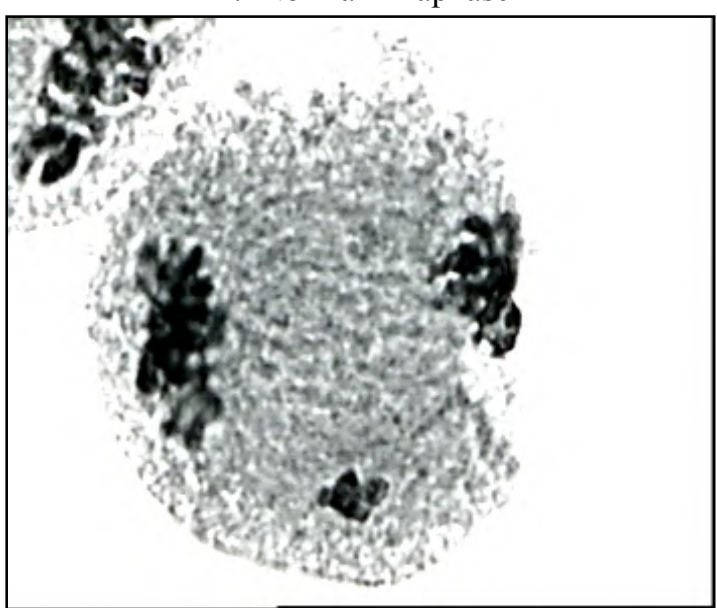

F. Laggard at Anaphase I

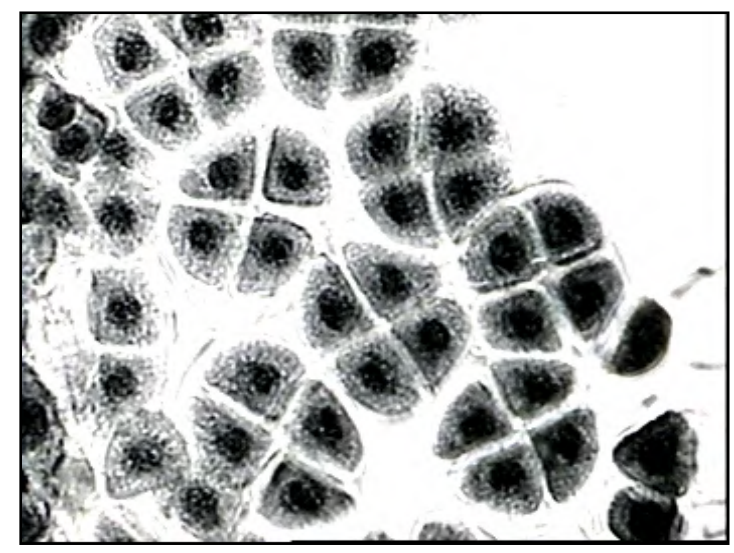

H. Normal Isobilateral Spore Tetrad

Plate 1 (E-H) Microphotographs showing various meiotic stages in Eleusine coracana 

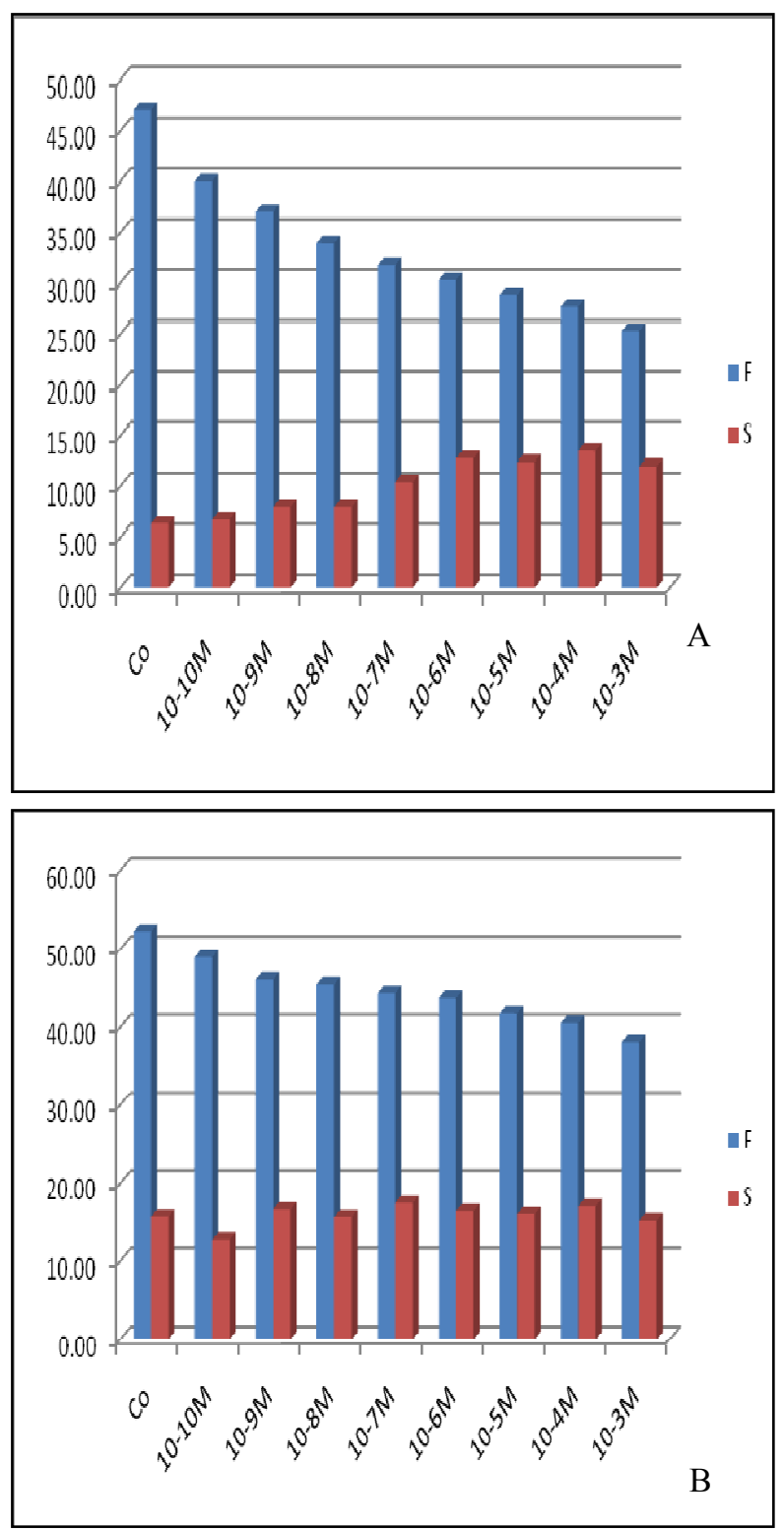

Fig. 1(A,B): Graph related to pollen fertility and ste-

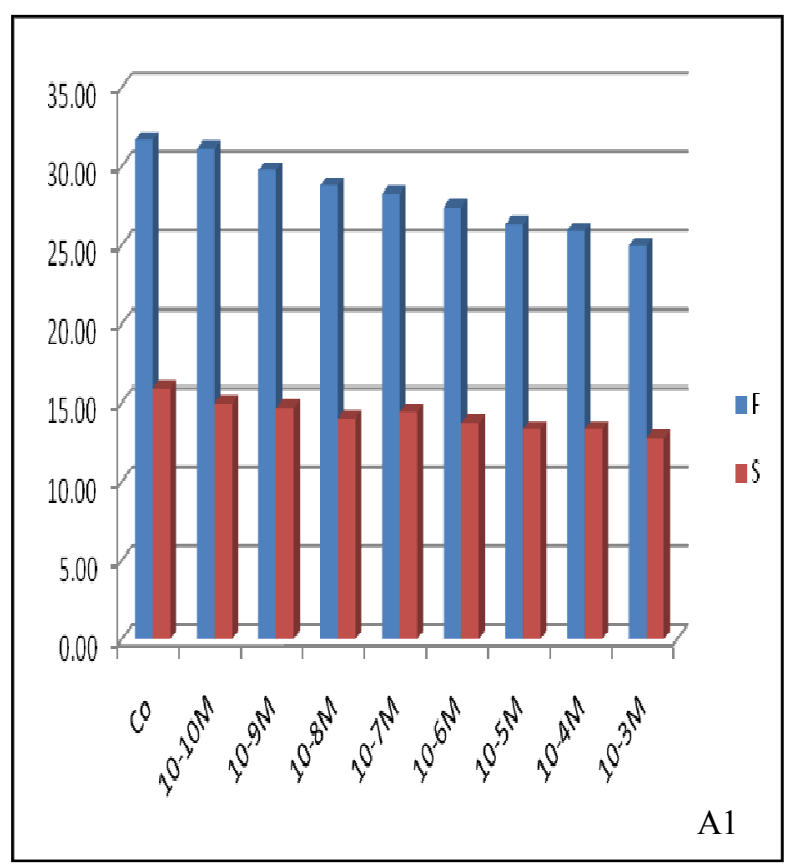

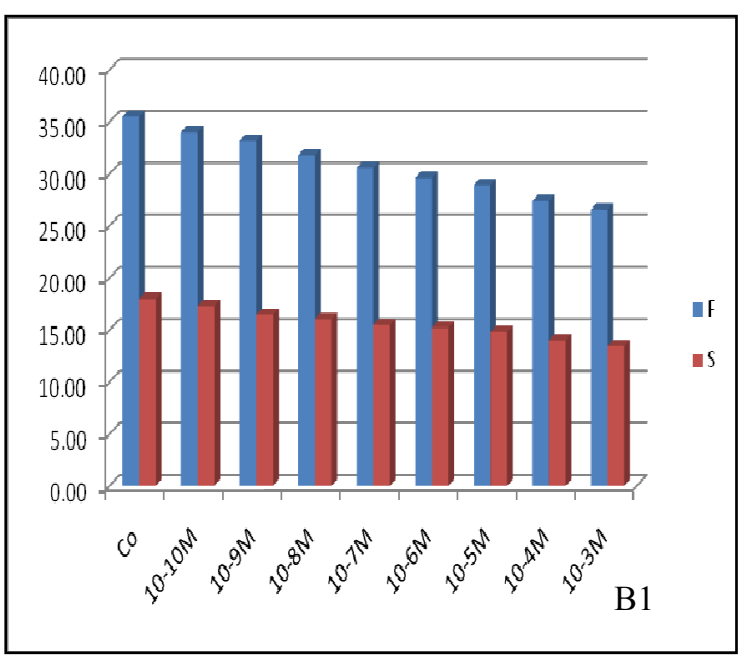

Fig. 2 (A1,B1): Graph related to pollen size $(\mu \mathrm{m})$ in E1 and E2 accessions of E. coracana

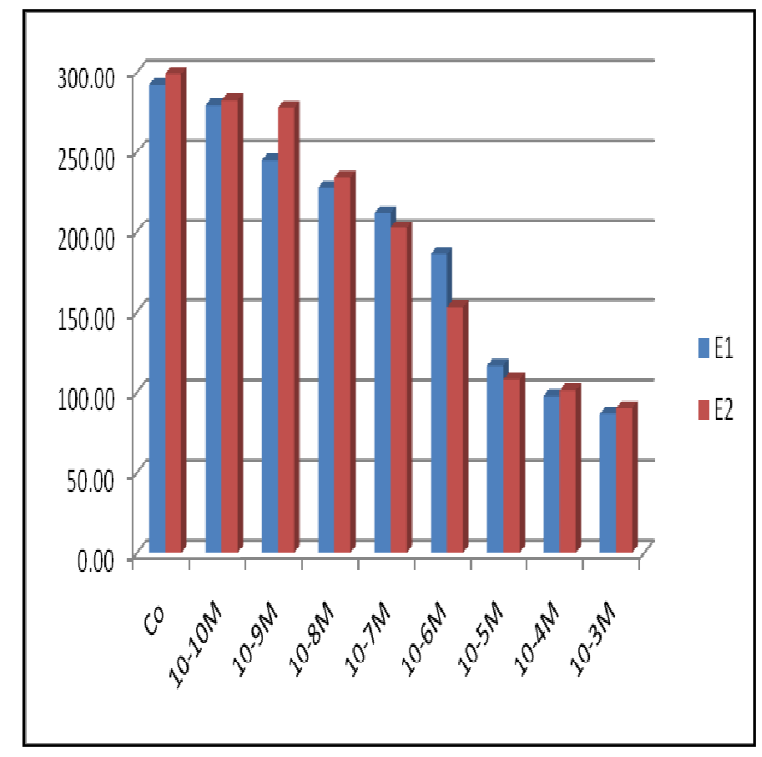

Fig. 3: Graph related to number of pollens per anther in different accessions of

\section{References}

Eapen, S. and George, L. (1989): High frequency plant regeneration through somatic embryo genesis in finger millet (Eleusine coracana L. Gaertn.) Plant Sci. 61:127-130.

Gaur, R. D. (1999): Flora of the district Garhwal Northwest Himalaya (with ethno botanical notes),302 and 662.

Kamble, M. S.; Dhonukshe, B. L.; Kashid, N. V. and Gavhane, V. N. (2004): Variability studies for weight of callus in finger millet [Eleusine coracana (L) Gaertn.] Res. on crops, 5(1): 66- 72. 
Kumar, S.; Agarwal, K. and Kothari, S. L. (2001): In vitro induction and enlargement of apical domes and formation of multiple shoots in finger millet, Eleusine coracana (L.) Gaertn and crowfoot grass, Eleusine indica (L.) Gaertn. Curr Sci. 81(11): 1482-1485.

Mohanty, B.; Dutta, D.; Gupta, S. and Ghosh, P. D. (1985): Callus initiation and plant regeneration in ragi (Eleusine coracana Gaertn.). Plant Cell Tiss. Org. Cult. 5: 147- 150.

Panda, P. R. (1999): Incorporating millets in high intensity cropping. Yojana.

Ramage, C. M. and Williams, R. R. (2002): Mineral nutrition and plant morphogenesis. In Vitro Cell Dev Biol Plant. 38:116-124.

Sivadas, P.; Kothari, S. L. and Chandra, N. (1990): High frequency embryoid and plantlet Formation from tissue cultures of the finger millet Eleusine coracana (L.) Gaertn. Plant Cell Rep. 9:93-96.

Watson, L. and Dallwitz, M. J. (1992): The grass genera of the world: descriptions, illustrations, identification, and information retrieval; including synonyms, morphology, anatomy, physiology, photochemistry, cytology, classification, pathogens, world and local distribution, and references. Version: 28th November 2005.

Panda, P. R. (1999): Incorporating millets in high intensity cropping. Yojana.

Ramage, C. M. and Williams, R. R. (2002): Mineral nutrition and plant morphogenesis. In Vitro Cell Dev Biol Plant. 38:116-124.

Sivadas, P.; Kothari, S. L. and Chandra, N. (1990): High frequency embryoid and plantlet Formation from tissue cultures of the finger millet Eleusine coracana (L.) Gaertn. Plant Cell Rep. 9:93-96.

Watson, L. and Dallwitz, M. J. (1992): The grass genera of the world: descriptions, illustrations, identification, and information retrieval; including synonyms, morphology, anatomy, physiology, photochemistry, cytology, classification, pathogens, world and local distribution, and references. Version: 28th November 2005. 